\title{
Changes in the Hydrophobic Proteins in Response to Biotin Administration in Serum of Infant Patients with Alopecia as Assessed by the Protein Micro-Sequencing Method
}

\author{
Kiyomi Abe', Kou Hayakawa ${ }^{2,5 *}$, Kenji Ihara ${ }^{3}$, Kentaro Deguchi ${ }^{4}$ and Takeaki Nagamine ${ }^{1}$ \\ ${ }^{1}$ Department of Pediatrics, School of Medicine, Keio University, 35 Shinano-machi, Shinjuku-ku, Tokyo, 160-8582, Japan \\ ${ }^{2}$ Graduate School of Health Sciences, Gunma University, 3-39-15, Showa-machi, Maebashi, Gunma 371-8514, Japan \\ ${ }^{3}$ Department of Pediatrics, Graduate School of Medical Sciences, Kyushu University, 3-1-1 Maidashi, Higashi-ku, Fukuoka, Fukuoka 812-8582, Japan \\ ${ }^{4}$ Department of Neurology, Graduate School of Medicine and Dentistry, Okayama University, 2-5-1 Shikada-cho, Okayama, Okayama 700-8558, Japan
}

\begin{abstract}
Introduction: In order to clarify the mechanism of hair growth induced by biotin, we compared the serum proteins before and after the oral biotin administration.

Materials and methods: The serum of three biotin-deficient children with alopecia were studied. Oral biotin administration was performed. Component proteins of serum were studied by using unique quantitative proteinmicrosequencing-deciphering method.

Results: Hydrophobic membrane-proteins of ultra-high-sulphur keratin-associated protein was detected in the serum of biotin-deficient children with alopecia. This membrane protein in the serum disappeared after the biotin administration. This phenomenon is significant ( $p<0.05$; Mann-Whitney's $U$ test).

Conclusion: Biotin deficiency in children induced the excretion of membrane proteins into the blood, and biotin administration prevented this phenomenon. Therefore, biotin was expected to regulate the expression of membrane proteins.
\end{abstract}

Keywords: Microsequencing; Biotin deficiency; Alopecia; KeratinAssociated protein; Human serum; Membrane protein; Glycoprotein; gait disorder.

Abbreviations: KAP: keratin-associated protein; UHS: ultra-highsulphur; ATX: ataxin ; OR: olfactory receptor; PLXA: plexin A; PDMD: Protein-Direct-Microsequencing-Deciphering; GSD1b: Glycogen storage disease type 1B.

\section{Introduction}

Successful oral biotin therapy in an alopecia girl with GSD-1b has been recently reported [1]. Thus, serum proteins of this patient are comparatively studied during biotin administration by using protein-direct-microsequencing deciphering (PDMD) method. This proteomics based upon the Edman-degradation [2] is general and quantitative identification method, which is applicable to tissue and cellular proteins [3].

In this paper, we report that ultra-high-sulphur keratin-associated protein (UHS-KAP) [4] and olfactory receptor (OR) [5] appear in the alopecia children's sera, and disappear by the biotin administration.

Further, we present the result of the comparative study of the adult serum of patient:with gait disorder and contraction (narrowing of visual field). The patient's serum contained plexin A (PLXA) [6] and OR, and ataxin (ATX) [7]. We also describe a finding that adult sera contain very-large protein-fragments of connectin/titin (mean molecular weight; 2,000,000) [8], which is absent in children's sera.

We also give an idea that the biotin deficiency induces the excretion of unique membrane-proteins into the blood from the tissues, and that oral free-biotin administration prevents this phenomenon. Thus, we propose the idea that biotin (vitamin $\mathrm{H}$ ) is a regulator of the expression of the membrane proteins, which is elucidated by using PDMD method.

\section{Materials and Methods}

\section{Chemicals and reagents}

Standard PTH-amino acids (mixture of 20 amino acids), 1-ethyl-3-(3-dimethyl-aminopropyl)-carbodiimide (EDC), pyridine (biochemical grade), 4-vinylpyridine, tri- $n$-butylphosphine, and TFAtreated glass fiber disk were obtained from Wako (Osaka, Japan). Fucosidase (from bovine kidney) and heparin (from porcine intestine) were purchased from Sigma (St. Louis, MO, USA). Neuraminidase (sialidase; from Vibrio cholerae) was from Roche Diagnostics Japan (Tokyo, Japan). Fermented beverage Yakult from cow's milk (Yakult Honsha Co., Tokyo, Japan) was purchased from a food shop, and Lactobacillus casei (Shirota) cells were purified from Yakult as reportedly [9]. Fucoidan was purified from a brown seaweed SilkyMozuku (Kinu-Mozuku; Nemacystis decipiens), which was from Noto-mae Koh-sushi Co., Anamizu-machi, Housu-gun, Ishikawa, Japan. Human serum and milk were kindly donated from the National Center for Child Health and Development (Tokyo, Japan) and from the Graduate School of Medicine and Dentistry, Okayama University (Okayama, Japan). Human sera of three biotin-deficient children and a

*Corresponding author: Kou Hayakawa, Graduate School of Health Sciences Gunma University, 3-39-15, Showa-machi, Maebashi, Gunma 371-8514, Japan, Tel: +81-48-548-1733; Fax: +81-48-548-1733; E-mail: amokha123@true.ocn.ne.jp

Received December 26, 2014; Accepted January 28, 2015; Published February 05, 2015

Citation: Abe K, Hayakawa K, Ihara K, Deguchi K, Nagamine T (2015) Changes in the Hydrophobic Proteins in Response to Biotin Administration in Serum of Infant Patients with Alopecia as Assessed by the Protein Micro-Sequencing Method. J Microb Biochem Technol 7: 039-046. doi:10.4172/1948-5948.1000179

Copyright: (c) 2015 Abe K, et al. This is an open-access article distributed under the terms of the Creative Commons Attribution License, which permits unrestricted use, distribution, and reproduction in any medium, provided the original author and source are credited 
Citation: Abe K, Hayakawa K, Ihara K, Deguchi K, Nagamine T (2015) Changes in the Hydrophobic Proteins in Response to Biotin Administration in Serum of Infant Patients with Alopecia as Assessed by the Protein Micro-Sequencing Method. J Microb Biochem Technol 7: 039-046. doi:10.4172/1948-5948.1000179

control healthy-female baby, and one adult biotin-deficient family and two healthy male adults were studied.

\section{Human Sera Analysed in this Text}

The measurement of serum concentration of biotin, urinary organic acid analysis, and blood acylcarnitine analysis are helpful in diagnosing the biotin deficiency. Therefore, low serum concentration of free biotin; by HPLC method. Low serum carnitine level; by the tandem mass-spectrometry) (MSMS). Abnormal urinary elevations of 3-methylcrotonyl-glycine, 3-hydroxyisovaleric acid, and methylcitric acid; by organic acid analysis with gas-chromatography/massspectrometry (GCMS). Remarkable elevations of C5-OH acylcarnitine (carnitine with fatty acyl C5-chain with hydroxyl-group), and propionylcarnitine $(\mathrm{C} 3)$ /acetylcarnitine $(\mathrm{C} 2)$ moles ratio $(\mathrm{C} 3 / \mathrm{C} 2$ ratio); by blood MS/MS analysis of acylcarnitine. Consequently, we diagnosed these patients as having biotin deficiency, and analysis of the sera was done on these patients and healthy controls as follows [1].

Child patient 1 with biotin-deficiency and alopecia, $3 y$ female, with GSD1b [1]. She showed eczema and sore around eyes and mouth, and hypoglycemic encephalopathy [1]. This patient received her father's liver by transplantation at the age of 3 y 6 mo in the National Center for Child Health and Development, Tokyo, Japan.

Child patient 2 with biotin-deficiency and alopecia due to allergy milk, 3 mo male. He showed eczema and sore around eyes, mouth, and genital area. (Supplementary data 1).

Child patient 3 with biotin-deficiency and alopecia due to allergy milk, 1 y female. She showed eczema and sore around eyes, mouth, and genital area. Diarrhea has been occurring. (Supplementary data 2). data 3 ).

Healthy child control 4 (with gastritis), 8 mo female (Supplementary

Healthy child control 4' (with common cold and inflammation), 12 mo female, and this child is the same person to the Healthy child control 4 (Supplementary data 3 ).

Adult patient 5 with biotin-deficiency, gait disorder, and contraction (narrowing of visual field), $32 \mathrm{y}$ female. She showed no skin eruption (Supplementary data 3).

Adult patient's sister 6 with slight gait disorder and contraction, 22 $\mathrm{y}$ female (with a slight biotin-deficiency, Supplementary data 3 ).

Adult patient's mother 7, healthy, 52 y (Supplementary data 3)

Adult healthy control 8, 33 y male (Supplementary data 3 ).

Adult healthy control 9, 20 y male.

We previously described that allergic conjunctivitis, bronchial asthma, and allergic rhinitis were detected in the atopic dermatitis children of the age between 9 and 14 years old [10]. However, these symptoms were not detected in our three patients of the age between 3 months and 3 years old.

Informed consent to use the serum samples for research was obtained from all the patients or their parents. The patients' photographs were produced with the permission from their parents. These studies were approved from the institutional and/or hospital's committees for the study of human rights.

\section{Protein-Direct-Microsequencing-Deciphering (PDMD) of the serum}

Quantitative direct-microsequencing was performed as previously described $[3,11]$ by using PPSQ-2l A protein sequencer (Shimadzu, Kyoto, Japan). Proteins were bound covalently by the EDC according to method of Salnikow et al. [12]. Labile cysteine was determined after the pyridylethylation and determined as the pyridylethyl-cysteine (PEC; S-[2-(4-pyridyl)ethyl]-L-cysteine), and data analyses of the obtained chromatograms were performed as described previously [3].

Direct-microsequencing was performed using a $0.08 \mathrm{~mL}$ of diluted serum sample (adjusted to $1 \mathrm{mg} / \mathrm{mL}$ by protein value of the serum by the HPLC size-exclusion chromato-graphic (SEC) protein determination method [13]. The quantitative serum dilution wasachievable by the dilution of serum with the $0.1 \mathrm{M}$ sodium phosphate buffer $(1 \mathrm{mM}$ EDTA, 10\% (v/v) glycerol, $\mathrm{pH} 6.8)$ [13].

$1^{\text {st }}, \mathrm{HbA}$ was estimated. $2^{\text {nd }}$, ceruloplasmin (mature (19-), and the unique fragment (214-)), transferrin (precursor (1-)), albumin, and alpha-fetoprotein (AFP) were then estimated. $3^{\text {rd }}$, sequences of serum biotinidase ([D, A, K, S]-[Q, N, H]-[P, D, N]-G-[E, D]-[V, P]-A-V-AD-V-[A, E, F]-[Q, F, L]-[V, A]-Y-; derived by us from Japanese sera for a blood transfusion ) [13] and kidney biotinidase (AVPPQVGNGQEGQTN-; unpublished result derived from the urine of Italian healthy male adult) were estimated. The sequence of milk biotinidase (FPSYVAVTKV- VPPYG-; unpublished result derived from the Japanese lactating women) was not detected in the human serum, but was surely detected in the human milk (Supple-mentary data 4) and in fetal liver cells (Hc cells) [3]. The sequence of serum biotinidase that was cloned by the liver of American (AHTGEESVADHHEAE-; italics indicated the same amino acid to our sequence of serum biotinidase) reported by Cole et al. [15] was appeared in the fetalliver cells (Hc cells) and sera of the inflammation patient. Therefore, reported sequence by Cole et al. [14] might be re-named as the fetal/inflammatory biotinidase. Without using these biotinidase sequences, the following database research could not be continued. Data searchwas done using the protein database tool of Protein BLAST (Basic Local Alignment Search Tool) of NCBI (National Center for Biotechnology Information) at the URL http://www.ncbi.nlm.nih.gov/pubmed.

If database research was suddenly stopped, the database search on viral, bacterial, fungal, or plant proteins was done. Then, the matching of sequence was usually occurred, and the protein of invaded microbe was chosen (Supplementary data 3 (serum) and 5 (liver biopsies)).

$\mathrm{N}$-Terminal sequences of immunoglobulin $\mathrm{G}$ ( $\mathrm{IgG})$ were varying (1-126 of the mature chain), then the database for the natural IgG was not obtainable. Thus, the consideration for the presence of about $15 \%$ IgG was incorporated. If the search was not possible to perform, then this situation was the termination point in PDMD algorithm. $\mathrm{N}$-Terminal of serum orosomucoid ( $\alpha$ - 1 acidglycoprotein; QIP-) was pyroglutamic acid, and was not measurable in this micro-sequencing method. Serine-type human serum lipoamidase was also not measurable by the possible N-terminal blockade. N-Terminal hydrophilic serum proteins such as transferrin (VPD-) and haptoglobin (VDS-) might be partially glycated, and ceruloplasmin (19-; AKE-) (214-; DRE-), $\alpha-2$ macroglobulin (SVS-), complement c3 ( $\alpha-$; SVQ-, $\beta$-; SPM-), and $\alpha-1$ antitrypsin (EDP-) might be partially closed by acetylation. But, this sequencing machine could measure the $\mathrm{N}$-terminal acetylated proteins; i.e., N-terminal acetylated protein of bovine heart cytochrome c (GDV-) could surely be analyzed by this machine. However, orosomucoid and human serum lipoamidase were dismissed by us, since these proteins 
Citation: Abe K, Hayakawa K, Ihara K, Deguchi K, Nagamine T (2015) Changes in the Hydrophobic Proteins in Response to Biotin Administration in Serum of Infant Patients with Alopecia as Assessed by the Protein Micro-Sequencing Method. J Microb Biochem Technol 7: 039-046. doi:10.4172/1948-5948.1000179

were considered to be minor components in the serum. PTH-amino acids from IgG molecules in serum were randomly accumulated to the considerable amounts. On the contrary to the case of tissues, database research for the serum was usually ended at the PTH-amino acids still remained. However, about 40 sequences could be searched, and about 80 proteins and protein fragments were detected in human serum samples. It was noteworthy that connectin/titin in the serum was a unique marker for adult (Supplementary data 3).

It was also interesting that the constantly present soluble proteins and transitory present proteins of cellular origin were co-exist. Presence of proteins (soluble cellular proteins and hydro-phobic membrane proteins, and the membrane glycoproteins) of tissue origin (mammary gland) was recently found in the commercial lactoferrin (derived from the cow's milk, Sigma L9507) [16].

\section{Determination of Hydrophobicity of the Protein and Protein Fragment}

Hydrophobicity of proteins was defied as: Hydrophobicity=1 Hydrophilicity [3]. Hydrophilicity was determined as follows: (Asx + $\mathrm{Thr}+\mathrm{Ser}+\mathrm{Glx}+$ Lys + His + Arg)/(total amino acid) [3] . Hydrophilicity and hydrophobicity were calculated by using a protein database tool of ProtParam at the URL

http://web.expasy.org/cgi-bin/protparam/protparam.

Hydrophobicity larger than 0.55 was considered to be the hydrophobic membrane-protein [3].

\section{Estimation of the Attachment of Glycochain onto Protein Fragment}

Possible attachment of an $\mathrm{N}$-linked glycochain onto the protein fragment was searched by using the protein database tool of the netNglyc server at a URL

\section{http://www.cbs.dtu.dk/services/NetNGlyc/.}

This netNglyc server predicted N-glycosylation site in the human proteins using artificial neural network that examined the sequence context of Asn-Xaa-Ser / Thr sequon.

\section{Biotin Administration}

Oral biotin administration was performed as described previously [1].

\section{Biotin Measurement}

Serum total- and free-biotin were determined by the affinity-HPLC method as described previously $[17,18]$.

\section{Biotinidase Activity}

Biotinidase (EC 3.5.1.12) activity in the serum was determined by an RP-HPLC method as described previously [9]. Thermal instability test was also performed by incubating the diluted serum by the $0.1 \mathrm{M}$ sodium phosphate buffer ( $1 \mathrm{mM}$ EDTA, 10\% (v/v) glycerol, $\mathrm{pH} 6.8$ [13]) for $4 \mathrm{~h}$ at $37^{\circ} \mathrm{C}$ [18]. Effect of fucoidan and heparin were tested at $0.20 \mathrm{mg} / \mathrm{mL}$ in the reaction mixture. Glycosidase (neuraminidase or fucosidase) treatment was performed by using diluted serum at 0.10 $\mathrm{U}$ of glycosidase $/ \mathrm{mL}$ of the reaction mixture for $4 \mathrm{~h}$ at $37^{\circ} \mathrm{C}$, and then treated serum was used immediately for biotinidase assay.

\section{Statistics}

Since the numbers of human sera were insufficient for estimating the distribution pattern and the biochemical phenomena possibly might have no parametric-distribution patterns, non-parametric analysis was performed as described previously [18]. Then, the data values were indicated as median and range.

\section{Results}

The child's serum of biotin deficiency with alopecia (Child patient 1) [1] was analyzed by a proteomics (PDMD method), and the appearance of membrane protein of ultra-high-sulphur- type keratin associated protein (UHS-KAP) in her serum is found (Table 1, left portion). The membrane protein olfactory receptor (OR) is also found in her serum, but this OR-fragment contains no glycochain. Control sera of Healthy child control 4, Healthy child control 4', and Adult healthy control 8 do not contain these two membrane proteins at all (Supplementary data 3). The oral biotin-administration on this alopecia patient at $10 \mathrm{mg} /$ day indicates that these two membrane proteins are surely disappeared in her serum (Table 1, right portion), and simultaneously her alopecia is completely healed [1]. Other two similar patients (Child patient 2 (two sera) and Child patient 3 (three sera)) also show the same phenomenon of appearance and disappearance of UHS-KAP and OR (Supplementary data 3). This phenomenon is found to be significant ( $\mathrm{p}$ $<0.05$; Mann-Whitney's U test: $\mathrm{n}_{1}$ (before biotin $)=3, \mathrm{n}_{2}$ (after biotin $)=4$; one-tailed test).

Proteins from microbes in sera of healthy controls are present at 4.5\% (Healthy adult control 8), 10.8\% (Adult patient's mother 7), and $7.9 \%$ (Healthy child control 4); i.e., median of healthy serum is $7.9 \%$; $\mathrm{n}_{1}=3$, and range is from 4.5 to $10.8 \%$. However, proteins from microbes in the inflammatory serum (common cold case and biotin deficiency cases; $\mathrm{n}_{2}=6$; median $15.8 \%$; range $14.3 \sim 18.5 \%$ ) are significantly increased $\left(\mathrm{p}<0.05 ; \mathrm{n}_{1}=3\right.$ (healthy), $\mathrm{n}_{2}=6$ (inflammatory); MannWhitney's U test, two-tailed test: Supplementary data 3). Liver tissues of various hepatic diseases $(\mathrm{n}=5)$ also show high content of virus and bacteria (median; 18.6\%, range; 15.1 - 30.2\%) (Supplementary data 5). With respect to proteins from virus, the content of viral proteins in sera is not unexpectedly correlated to the inflammatory diseases (median 3.2\%; n=9; Supplementary data 3). But, the hepatoma cancer cells (HepG2) contain relatively high amount (6.6\%) of viral proteins [3].

Unique fragment of ceruloplasmin (from 214-) in the serum is found to be a good indicator of inflammation; i.e., concentration of the ceruloplasmin-fragment in the serum of healthy controls is $0.0 \mu \mathrm{g} /$ $m g$ of serum proteins $\left(\mathrm{n}_{1}=3\right)$, however that of inflammatory diseases is significantly increased $(2.1 \mu \mathrm{g} / \mathrm{mg}$ of serum proteins; range $0.0-4.0 \mu \mathrm{g} /$ mg of serum proteins; $\left.\mathrm{n}_{2}=10\right)(\mathrm{p}<0.02 ;$ Mann-Whitney's $\mathrm{U}$ test, twotailed test; Supplementary data 3 ). With respect to the inflammation, the affinity to the substrate (biotinyl-6-aminoquinoline) of biotinidase (Amo) in inflammatory disease is also found to be significantly increased; i.e., median Amo in inflammatory diseases $(n=10)$ is $23.9 \mathrm{~s}^{-1}$ $\mathrm{x} \mathrm{M}^{-1}$ and that in healthy control $(\mathrm{n}=8)$ is $19.4 \mathrm{~s}^{-1} \mathrm{x} \mathrm{M}^{-1}$, respectively ( $\mathrm{p}<0.002$; Mann-Whitney's $\mathrm{U}$ test, two-tailed test). This finding is in line with the previous finding that specific activity $(V)$ of biotinidase is instantaneously elevated in cerebrospinal fluid of a Staphylococcus aureus meningitis patient [18].

Surprisingly, protein amount of biotinidase in the serum is not changed by the oral biotin-administration at all; i.e., Child patient 1 from 0.19 to $0.19 \mathrm{mg} / \mathrm{mL}$, Child patient 2 from 0.20 to $0.22 \mathrm{mg} / \mathrm{mL}$, and Child patient 3 from 0.25 to $0.21 \mathrm{mg} / \mathrm{mL}$ before and after the biotin treatment, respectively (Table 1 and Supplementary data 3 ).

The result of thermal instability test of serum biotinidase in the biotin-deficient patients is summarized in Table 3. Biotinidase is an 
Citation: Abe K, Hayakawa K, Ihara K, Deguchi K, Nagamine T (2015) Changes in the Hydrophobic Proteins in Response to Biotin Administration in Serum of Infant Patients with Alopecia as Assessed by the Protein Micro-Sequencing Method. J Microb Biochem Technol 7: 039-046. doi:10.4172/1948-5948.1000179

\begin{tabular}{|c|c|c|c|}
\hline \multicolumn{2}{|l|}{ Before biotin treatment } & \multicolumn{2}{|l|}{ After biotin treatment $(8 \mathrm{mo})$} \\
\hline Proteins & $\begin{array}{c}\text { Amount } \\
(\mu \mathrm{g} / \mathrm{mg} \text { serum protein) }\end{array}$ & Proteins & $\begin{array}{c}\text { Amount } \\
\text { ( } \mu \mathrm{g} / \mathrm{mg} \text { serum protein) }\end{array}$ \\
\hline Human serum albumin (1-) & 422 & Human serum albumin (1-) & 227 \\
\hline Keratin-associated protein 4-1 (29-) & 19.3 & von Willebrand factor $\mathrm{C}$ domain-containing protein 2-like (93-) & 83.0 \\
\hline Hemopexin (Hyaluronidase; 361-) & 19.3 & Membrane-spanning 4-domains subfamily A member 10 (136-) & 42.0 \\
\hline Probable E3 ubiquitin-protein ligase HERC2 (4755-) & 12.5 & Estrogen sulfotransferase (178-) & 18.4 \\
\hline $\begin{array}{c}\text { Leucine-rich repeat transmembrane neuronal } \\
\text { protein } 1 \text { (424-) }\end{array}$ & 11.7 & Signal-induced proliferation-associated protein 1 (704-) & 18.3 \\
\hline Alpha-2-Macroglobulin receptor-associated protein (86-) & 10.7 & Serum amyloid P-component (120-) & 16.5 \\
\hline MAP kinase-activating death domain protein (373-) & 10.1 & Antisecretory factor $1(120-)$ & 14.8 \\
\hline Histone-lysine N-methyltransferase MLL3 (250-) & 9.3 & Cathepsin S (40-) & 14.0 \\
\hline ATP-dependent helicase CHD1 (1595-) & 9.1 & Cell cycle control protein 50C (26-) & 13.9 \\
\hline HBxAg transactivated protein 2 (728-) & 8.6 & 39S Ribosomal protein L9, mitochondrial (183-) & 13.5 \\
\hline Ceroid-lipofuscinosis neronal protein 6 (87-) & 7.0 & Integrin alpha-4 (55-) & 11.2 \\
\hline $\begin{array}{l}\text { RNA polymerase-associated protein CTR9 } \\
\text { homolog (822-) }\end{array}$ & 7.0 & Transferrin (1-) & 10.8 \\
\hline Embryonal Fyn-associated substrate (473-) & 7.0 & Mucin-6 (715-) & 10.8 \\
\hline Zinc finger protein 441 (581-) & 6.2 & Zinc finger protein 800 (354-) & 9.9 \\
\hline Nuclear autoantigenic sperm protein (710-) & 6.2 & Beta-Ketoacyl-ACP synthase (356-) & 9.9 \\
\hline Importin-11 (212-) & 6.1 & Diphthamide biosynthesis protein 1 (141-) & 9.7 \\
\hline Olfactory receptor $5 \mathrm{~A} 2(\mathrm{OR} ; 21-)$ & 6.0 & Mannose receptor-like protein 2 (285-) & 8.7 \\
\hline Mutated in bladder cancer protein 1 (170-) & 5.4 & Equilibrative nucleoside transporter 3 (224-) & 6.3 \\
\hline Vacuolar proton pump subunit $\mathrm{H}(416-)$ & 5.3 & DNA-dependent protein kinase catalytic subunit (381-) & 5.9 \\
\hline $\begin{array}{l}\text { Potassium voltage-gated channel subfamily H } \\
\text { member } 5(320-)\end{array}$ & 5.3 & Ribonucleotide reductase small subunit (86-) & 5.8 \\
\hline $\begin{array}{l}\text { Calcium-binding mitochondrial carrier protein } \\
\text { SCaMC-1 (427-) }\end{array}$ & 4.9 & Transmembrane protease, serine 9 (715-) & 5.5 \\
\hline Sodium bicarbonate transporter-like protein 11 (118-) & 4.9 & Extracellular matrix protein $2(550-)$ & 5.4 \\
\hline $\begin{array}{l}\text { Immunoglobulin-like and fibronectin type III } \\
\text { domain-containing protein } 1 \text { (641-) }\end{array}$ & 4.8 & Lysosomal-trafficking regulator (2147-) & 5.3 \\
\hline Transferrin (1-) & 4.6 & Cysteine-rich motor neuron 2 protein (151-) & 5.1 \\
\hline Interleukin-9 receptor (295-) & 4.5 & $\mathrm{~N}$-myc downstream-regulated 1 porotein (248-) & 4.7 \\
\hline Retinoic acid-induced protein 2 (341-) & 4.4 & Triple functional domain protein (288-) & 4.4 \\
\hline Mutated in bladder cancer protein 1 (170-) & 5.4 & Equilibrative nucleoside transporter 3 (224-) & 6.3 \\
\hline Serotonin receptor 4 (169-) & 4.4 & Alpha2-Macroglobulin (1-) & 4.2 \\
\hline Complement factor $\mathrm{H}$-related protein $3(121-)$ & 4.2 & Renal carcinoma antigen NY-REN-36 (1254-) & 4.1 \\
\hline Inositol monophosphatase 3 (107-) & 3.9 & Remained Fibrinogen (2-) & 4.0 \\
\hline Immunogloblin superfamily member 3 (254-) & 3.7 & Paternally-expressed gene 3 protein (1341-) & 4.0 \\
\hline E3 ubiquitin-protein ligase UBR3 (877-) & 3.2 & Alpha-fetoprotein (AFP; 1-) & 3.8 \\
\hline Huntingtin-interacting protein HIP3RP (462-) & 3.1 & Receptor tyrosine-protein kinase ErbB-1 (EGF receptor; 280-) & 3.6 \\
\hline Ceruloplasmin (19-) & 0.6 & Mediator complex subunit 14 (667-) & 3.5 \\
\hline Uncharacterized protein C17orf53 (438-) & 3.4 & Ceruloplasmin (214-) & 2.7 \\
\hline $\begin{array}{l}\text { Alanine-glyoxylate aminotransferase } 2 \text {, } \\
\text { mitochondrial (110-) }\end{array}$ & 3.3 & ATP synthase subunit gamma, mitochondrial (103-) & 3.1 \\
\hline Ubiquitin thioesterase 27 (48-) & 3.3 & Biotinidase (serum sequence) (1-) & 2.8 \\
\hline Solute carrier family 22 member 14 (446-) & 3.0 & Transcription initiation factor TFIID subunit 3 (515-) & 2.7 \\
\hline Alpha2-Macroglobulin (1-) & 3.0 & Beta-1,4 N-acetylgalactosaminyltransferase 1 (120-) & 2.7 \\
\hline Dyslexia susceptibility 1 candidate gene 1 protein (272-) & 3.0 & A-kinase anchor protein 13 (2396-) & 2.7 \\
\hline Biotinidase (serum sequence) (1-) & 2.8 & Alpha1-Antitrypsin (25-) & 2.5 \\
\hline Patched domain-containing protein 1 (186-) & 2.7 & Glycosyltransferase 1 domain-containing protein 1 (196-) & 2.4 \\
\hline C-type lectin domain family 4 member D (41-) & 2.7 & Patched domain-containing protein 1 (186-) & 2.7 \\
\hline A disintegrin and metalloproteinase domain 22 (319-) & 2.3 & USP6 N-teminal-like protein (432-) & 2.3 \\
\hline Bile salt export pump (737-) & 2.3 & Centrosomal protein of $110 \mathrm{kDa}(545-)$ & 2.1 \\
\hline Alpha-fetoprotein (AFP; 1-) & 1.9 & Tyrosine-protein kinase receptor ETK1 (562-) & 1.6 \\
\hline Remained Fibrinogen (2-) & 1.7 & Myotubularin-related protein 8 (233-) & 1.5 \\
\hline HBV X-associated protein 1 (618-) & 1.7 & Ribonuclease inhibitor (86-) & 1.5 \\
\hline Alpha1-Antitrypsin (25-) & 1.6 & Beta-1,4-Galactosyltransferase 6 (12-) & 1.5 \\
\hline Brain calcium channel II (1883-) & 1.4 & & \\
\hline Patched domain-containing protein 1 (186-) & 2.7 & Glycosyltransferase 1 domain-containing protein 1 (196-) & 2.4 \\
\hline Total & 701 & Total & 666 \\
\hline Invaded microbe's protein & 149 & Invaded microbe's protein & 184 \\
\hline
\end{tabular}

*Proteins coming from the cellular membranes were indicated in Italics. Glycochain synthetase were indicated as in bold. Serum of after biotin treatment is 8 mo after the biotin treatment. Transplantation operation of the liver from her father in this patient was performed after 6 mo from the initiation of the biotin treatment. IgG content was considered as $150 \mu \mathrm{g} / \mathrm{mg}$ serum protein. Membrane proteins present in the serum were estimated as $84 \mathrm{and} 32 \mathrm{\mu g} / \mathrm{mg}$ serum protein for before and after biotin treatment, respectively. Proteins of invaded microbes were shown in the Supplementary data 3 (excel tables).Other conditions were as described in the Materials and Methods section.

Table 1: Component serum proteins of Child patient 1 with GSD1b before and after the biotin administration. 
Citation: Abe K, Hayakawa K, Ihara K, Deguchi K, Nagamine T (2015) Changes in the Hydrophobic Proteins in Response to Biotin Administration in Serum of Infant Patients with Alopecia as Assessed by the Protein Micro-Sequencing Method. J Microb Biochem Technol 7: 039-046. doi:10.4172/1948-5948.1000179

\begin{tabular}{|c|c|c|c|c|c|c|c|c|c|}
\hline & \multicolumn{5}{|c|}{ Proteins } & \multirow{3}{*}{$\begin{array}{c}\text { Membrane } \\
\text { proteins } \\
\text { ( } \mathrm{\mu g} / \mathrm{mg} \text { serum } \\
\text { protein) }\end{array}$} & \multirow{3}{*}{$\begin{array}{c}\text { Microbes } \\
(\%)\end{array}$} & \multicolumn{2}{|c|}{ Biotin } \\
\hline & \multirow[t]{2}{*}{ KAP } & \multirow[t]{2}{*}{ OR } & \multirow[t]{2}{*}{$P L X A$} & \multirow[t]{2}{*}{ ATX } & \multirow[t]{2}{*}{ Titin } & & & total & free \\
\hline & & & & & & & & \multicolumn{2}{|c|}{ ( $\mu \mathrm{g} / \mathrm{mL}$ serum) } \\
\hline \multicolumn{10}{|c|}{ Children's serum } \\
\hline \multicolumn{10}{|c|}{ Child patient 1 with GSD1b (3 y, female) } \\
\hline Before biotin & + & ND & ND & ND & ND & 84 & 14.9 & 3.08 & ND \\
\hline After biotin (32 w) & ND & ND & ND & ND & ND & 32 & 18.4 & 9.43 & 1.78 \\
\hline \multicolumn{10}{|c|}{ Child patient 2 ( 3 mo, male) } \\
\hline Before biotin & + & ND & ND & ND & ND & 38 & 16.2 & 2.31 & 0.54 \\
\hline After biotin (13 w) & ND & ND & ND & ND & ND & 18 & 15.0 & 3.89 & 0.23 \\
\hline \multicolumn{10}{|c|}{ Child patient 3 ( 1 y, female) } \\
\hline Before biotin & + & ND & ND & ND & ND & 55 & 14.3 & 2.03 & 0.036 \\
\hline After biotin (16 w) & ND & ND & ND & ND & ND & 10 & 21.6 & 2.56 & 0.31 \\
\hline After biotin (44 w) & ND & ND & ND & ND & ND & 44 & 17.5 & 7.25 & 0.10 \\
\hline \multicolumn{10}{|c|}{ Healthy baby control 4 ( $8 \mathrm{mo}$, female) (gastritis) } \\
\hline & ND & ND & ND & ND & ND & 7.0 & 7.9 & 3.21 & 0.18 \\
\hline \multicolumn{10}{|c|}{ Healthy but inflammatory control 4' (12 mo, female) } \\
\hline & ND & ND & ND & ND & ND & 24 & 15.4 & 3.22 & 0.66 \\
\hline \multicolumn{10}{|c|}{ Adult's serum } \\
\hline \multicolumn{10}{|c|}{ Adult patient $\mathbf{5}$ with gait disorder and contraction (narrowing of visual field) ( $32 \mathrm{y}$, female) } \\
\hline & ND & + & + & + & + & 62 & 18.5 & 1.14 & 0.04 \\
\hline \multicolumn{10}{|c|}{ Adult patient's sister 6 with light gait disorder (younger sister; 22 y, female) } \\
\hline & ND & ND & + & ND & + & 44 & 18.3 & 1.29 & 0.07 \\
\hline \multicolumn{10}{|c|}{ Adult patient's healthy mother 7 ( $52 \mathrm{y}$, female $)$} \\
\hline & ND & ND & ND & ND & + & 44 & 10.8 & 1.68 & NM \\
\hline \multicolumn{10}{|c|}{ Adult healthy control 8 (33 y, male) } \\
\hline & ND & ND & ND & ND & + & 38 & 4.5 & 1.80 & 0.12 \\
\hline
\end{tabular}

*PLXA; plexin A. ATX; ataxin. ND; not detectable. NM; not measured. OR and PLXA are protein-fragments without glycochains. KAP of Child patient 1 is 4-1, Child patient 2 is $5-5$, Child patient 3 is $4-8$, respectively, and all is ultra-high cysteine (UHS) type containing more than 30 mol \% cysteine. Other conditions were as described in the Materials and Methods section. Healthy control serum contained proteins of microbes at 4.5 and $7.9 \%$.

Table 2: Summary of various characteristics in the biotin deficient patients and healthy controls*.

$\mathrm{N}$-linked glycoprotein enzyme [14], and enzyme kinetics is influenced by the glycosidase treatment (Table 3 ). Serum of healthy control contains thermo-stable biotinidase, but the serum of biotin-deficient patient contains thermo-labile enzyme (Table 3). Therefore, the effect of polysaccharide fucoidan on the enzyme activity is tested in vitro. It is found that the heat-labile biotinidase $\mathrm{Km}$ of the biotin-deficient patients becomes heat-stable, but the other sulphated-polysaccharide of heparin does not (Table 3). Further, appearance of glycochain synthesizing enzymes in serum of biotin-treated Child patient 1 ( $8 \mathrm{w}$ of biotin treatment) is found as shown in Table 1 (right portion, in bold). Two other Child patients 2 and 3 also show similar phenomena; i.e., at $13 \mathrm{w}$ of treatment for Child patient 2, and at $16 \mathrm{w}$ of treatment for Child patient 3 (Supplementary data 3, in bold-brown).

Glycoprotein fragments of cytoplasmic proteins of ataxin-2 (ATX2) [20] and of ataxin-7-like protein 1 (ATX-7-like protein 1) [21] are detectable in the serum of biotin-deficient Adult patient 5 (with severe gait-disorder), but they are not present in the serum of Adult patient's sister 6 (not the true biotin-deficiency; Table 2 and Supplementary data 3). Sera of Adult patient 5 and Adult patient's sister 6 contain hydrophilic fragment of plexin-A (PLXA) without glycochain and with glycochain, respectively. (Table 2 and Supplementary data 3 ). The fragments of membrane protein of olfactory receptor (OR) are also detected in this family's serum, but only the fragment of biotin-deficient Adult patient 5 has glycochain. Furthermore, OR, ATX, and PLXA are not detectable in serum of a healthy adult control (Adult healthy control 8) (Table 2 and Supplementary data 3).

\section{Discussion}

KAP is an important component protein for the growth of hair [22]. All the KAP appeared in serum of biotin-deficiency is type of UHS-type (defined as containing more than $30 \mathrm{~mol} \%$ of cysteine) [4]; i.e., KAP 4-1(35.6 mol\%) in Child patient 1, KAP 5-5 (38.1 mol\%) in Child patient 2, KAP 4-8 (35.5 and $33.3 \mathrm{~mol} \%)$ in Child patient 3, respectively. Biotin is a known sulphur-containing vitamin. Human serum biotinidase is also known to handle with biotin and lipoic acid [23]. Therefore, biotin may have an important role to integrate the UHS-KAP into the membrane compartment via biotin.

Table 2 shows that membrane proteins present in the serum are reduced significantly by the biotin treatment (in the case of Child patient 3 ; the data of $16 \mathrm{w}$ is used). This result may indicate that sufficient biotin-supply in the body normalized the expression of the membrane proteins and membrane glycoproteins. However, Child patient 3 at 44 $\mathrm{w}$ of biotin-therapy shows the high content of membrane proteins in serum (Table 2). Further, abnormally high biotinidase $V(217 \mathrm{pmol} /$ $\mathrm{min} / \mathrm{mg}$ ) is observed at $44 \mathrm{w}$ (data not shown). Such symptoms of excess biotin-supply as anorexia and loss of weight are observed at 44 w (Supplementary data 3).

Therefore, biotin administration should be stopped within c.a. 4 mo.

Although the precise mechanism of phenomenon of the excretion of membrane proteins into the blood is not fully clarified, similar phenomenon of release of membrane glycoprotein of kidney biotinidase into the urine in juvenile insulin-dependent diabetes mellitus (IDDM) 
Citation: Abe K, Hayakawa K, Ihara K, Deguchi K, Nagamine T (2015) Changes in the Hydrophobic Proteins in Response to Biotin Administration in Serum of Infant Patients with Alopecia as Assessed by the Protein Micro-Sequencing Method. J Microb Biochem Technol 7: $039-046$. doi:10.4172/1948-5948.1000179

\begin{tabular}{|c|c|c|c|c|c|c|}
\hline Serum & Amo & $V \max$ & Km & Kip & Rep & Cap \\
\hline & $\mathbf{S}^{-1} \times \mathbf{M}^{-1}$ & $\begin{array}{c}\mathrm{pmol} / \\
\mathrm{min} / \mathrm{mg}\end{array}$ & $\mu \mathrm{M}$ & $\begin{array}{c}\text { by biotin } \\
(\mu \mathrm{M})\end{array}$ & $\begin{array}{c}\mathbf{s}^{-1} \times M \times \\
10^{-3}\end{array}$ & $\mathbf{s}^{-1}$ \\
\hline \multicolumn{7}{|c|}{ Healthy control (without inflammation) } \\
\hline \multicolumn{7}{|c|}{ Healthy adult control 9 (20 y, male) } \\
\hline Fresh & 19.1 & 123 & 8.16 & 689 & 107 & 45.2 \\
\hline Heat treatment & 16.0 & 105 & 8.30 & 861 & 114 & 42.7 \\
\hline With fucoidan & 14.2 & 95.2 & 8.47 & 794 & 95.5 & 36.8 \\
\hline With neuraminidase & 5.90 & 76.9 & 16.5 & 628 & 61.1 & 19.0 \\
\hline With fucosidase & 10.5 & 120 & 14.5 & 963 & 147 & 39.3 \\
\hline \multicolumn{7}{|c|}{ Healthy child control 4 (8 mo, female) (gastritis) } \\
\hline Fresh & 22.2 & 156 & 8.91 & 494 & 97.6 & 46.5 \\
\hline Heat treatment & 26.2 & 185 & 8.93 & 506 & 118 & 55.6 \\
\hline With fucoidan & 33.6 & 211 & 7.94 & 471 & 126 & 65.1 \\
\hline With heparin & 35.2 & 217 & 7.81 & 346 & 95.1 & 57.9 \\
\hline With neuraminidase & 24.0 & 179 & 9.43 & 247 & 55.9 & 36.6 \\
\hline With fucosidase & 38.0 & 131 & 4.37 & 157 & 26.1 & 31.5 \\
\hline \multicolumn{7}{|l|}{ Patients } \\
\hline \multicolumn{7}{|c|}{ Child patient 1 with GSD $1 b$ ( 3 y, female) } \\
\hline \multicolumn{7}{|l|}{ Before biotin } \\
\hline Fresh & 19.9 & 132 & 8.38 & 404 & 67.4 & 36.6 \\
\hline Heat treatment & 7.95 & 147 & 23.4 & 478 & 88.9 & 26.6 \\
\hline With fucoidan & 21.5 & 98.0 & 5.78 & 1410 & 175 & 61.3 \\
\hline With heparin & 13.0 & 139 & 13.5 & 202 & 35.5 & 21.5 \\
\hline With neuraminidase & 10.4 & 69.0 & 8.40 & 1140 & 99.6 & 32.2 \\
\hline With fucosidase & 12.0 & 127 & 13.4 & 430 & 69.2 & 28.8 \\
\hline \multicolumn{7}{|l|}{ After biotin (32 w) } \\
\hline Fresh & 17.5 & 101 & 7.30 & 530 & 67.7 & 34.4 \\
\hline Heat treatment & 9.41 & 113 & 15.2 & 549 & 78.5 & 27.2 \\
\hline With fucoidan & 33.8 & 122 & 4.57 & 317 & 49.0 & 40.7 \\
\hline With heparin & 21.5 & 99.5 & 5.85 & 769 & 96.7 & 45.6 \\
\hline With neuraminidase & 13.9 & 75.8 & 6.90 & 255 & 24.5 & 18.5 \\
\hline With fucosidase & 5.82 & 95.7 & 20.8 & 1250 & 152 & 29.7 \\
\hline \multicolumn{7}{|c|}{ Child patient 2 ( $3 \mathrm{mo}$, male) } \\
\hline \multicolumn{7}{|l|}{ Before biotin } \\
\hline Fresh & 25.5 & 182 & 9.02 & 365 & 83.9 & 46.3 \\
\hline Heat treatment & 8.63 & 122 & 17.9 & 271 & 41.8 & 19.0 \\
\hline With fucoidan & 33.6 & 143 & 5.39 & 760 & 138 & 68.1 \\
\hline With heparin & 26.3 & 233 & 11.2 & 765 & 225 & 76.9 \\
\hline With neuraminidase & 9.25 & 44.2 & 6.05 & 296 & 16.6 & 12.4 \\
\hline With fucosidase & 7.75 & 73.5 & 12.0 & 401 & 37.3 & 17.0 \\
\hline \multicolumn{7}{|l|}{ After biotin (1 w) } \\
\hline Fresh & 23.9 & 103 & 5.46 & 515 & 67.2 & 40.1 \\
\hline Heat treatment & 17.7 & 145 & 10.4 & 661 & 122 & 46.5 \\
\hline With fucoidan & 30.9 & 143 & 5.85 & 439 & 79.4 & 49.5 \\
\hline With heparin & 25.4 & 154 & 7.69 & 874 & 171 & 65.9 \\
\hline With neuraminidase & 3.22 & 57.5 & 22.6 & 1050 & 76.6 & 15.7 \\
\hline With fucosidase & 5.45 & 78.4 & 18.2 & 1450 & 144 & 28.0 \\
\hline \multicolumn{7}{|c|}{ Child patient 3 (1 y, female) } \\
\hline \multicolumn{7}{|l|}{ Before biotin } \\
\hline Fresh & 35.9 & 112 & 3.95 & 331 & 46.9 & 41.0 \\
\hline Heat treatment & 10.1 & 124 & 15.6 & 1310 & 206 & 45.6 \\
\hline With fucoidan & 16.8 & 116 & 8.73 & 424 & 62.2 & 32.3 \\
\hline With heparin & 10.5 & 122 & 14.7 & 1020 & 158 & 40.7 \\
\hline With neuramindase & 13.4 & 79.5 & 7.52 & 549 & 55.3 & 28.3 \\
\hline With fucosidase & 12.4 & 73.7 & 7.52 & 230 & 21.5 & 20.6 \\
\hline \multicolumn{7}{|l|}{ After biotin (1 w) } \\
\hline Fresh & 26.0 & 177 & 8.62 & 408 & 91.4 & 48.8 \\
\hline Heat treatment & 20.1 & 135 & 8.48 & 737 & 124 & 49.6 \\
\hline With fucoidan & 22.1 & 122 & 6.99 & 430 & 66.4 & 38.3 \\
\hline With heparin & 12.0 & 79.4 & 8.40 & 1690 & 171 & 45.3 \\
\hline
\end{tabular}

\begin{tabular}{|c|c|c|c|c|c|c|}
\hline With neuraminidase & 13.4 & 79.5 & 7.52 & 594 & 59.8 & 28.3 \\
\hline With fucosidase & 19.7 & 73.7 & 4.74 & 230 & 21.5 & 20.6 \\
\hline \multicolumn{7}{|c|}{$\begin{array}{l}\text { Adult patient } 5 \text { ( } 32 \mathrm{y} \text {, adult female) } \\
\text { (gait disorder, contraction (narrowing of visual field)) }\end{array}$} \\
\hline \multicolumn{7}{|l|}{ Before Ebios } \\
\hline Fresh & 18.4 & 63.6 & 4.45 & 342 & 27.7 & 22.4 \\
\hline Heat treatment & 16.6 & 500 & 38.2 & 265 & 168 & 52.8 \\
\hline With fucoidan & 17.3 & 125 & 9.13 & 609 & 96.2 & 40.8 \\
\hline With heparin & 21.8 & 155 & 9.01 & 277 & 54.4 & 34.4 \\
\hline With neuraminidase & 7.00 & 120 & 21.7 & 848 & 129 & 30.0 \\
\hline With fucosidase & 5.19 & 47.6 & 11.6 & 754 & 45.4 & 15.4 \\
\hline \multicolumn{7}{|l|}{ Before Ebios } \\
\hline Fresh & 18.4 & 63.6 & 4.45 & 342 & 27.7 & 22.4 \\
\hline Heat treatment & 16.6 & 500 & 38.2 & 265 & 168 & 52.8 \\
\hline With fucoidan & 17.3 & 125 & 9.13 & 609 & 96.2 & 40.8 \\
\hline With heparin & 21.8 & 155 & 9.01 & 277 & 54.4 & 34.4 \\
\hline With neuraminidase & 7.00 & 120 & 21.7 & 848 & 129 & 30.0 \\
\hline With fucosidase & 5.19 & 47.6 & 11.6 & 754 & 45.4 & 15.4 \\
\hline \multicolumn{7}{|c|}{ After Ebios +Yakult (16 w) } \\
\hline Fresh & 24.6 & 141 & 7.25 & 401 & 71.5 & 41.9 \\
\hline Heat treatment & 8.52 & 90.9 & 13.5 & 2760 & 318 & 52.1 \\
\hline With fucoidan & 8.86 & 67.6 & 9.66 & 2430 & 200 & 42.1 \\
\hline With heparin & 10.0 & 65.4 & 8.26 & 5400 & 446 & 66.8 \\
\hline With neuraminidase & 8.76 & 66.2 & 9.57 & 1100 & 92.5 & 28.5 \\
\hline With fucosidase & 10.2 & 155 & 19.2 & 899 & 176 & 42.4 \\
\hline \multicolumn{7}{|c|}{ After Ebios +Yakult (1.5 y) } \\
\hline Fresh & 14.2 & 132 & 11.8 & 417 & 69.9 & 31.5 \\
\hline Heat treatment & 4.51 & 75.8 & 21.3 & 543 & 52.2 & 15.3 \\
\hline With fucoidan & 17.7 & 77.2 & 5.51 & 444 & 43.3 & 27.7 \\
\hline With heparin & 15.5 & 147 & 12.0 & 670 & 125 & 44.0 \\
\hline With neuraminidase & 7.72 & 55.2 & 9.05 & 862 & 60.3 & 21.6 \\
\hline With fucosidase & 12.4 & 90.9 & 9.26 & 271 & 31.1 & 19.6 \\
\hline
\end{tabular}

${ }^{*}$ Parameters of biotinidase kinetics were expressed according to the ref. 9. Thermal instability test was performed as in ref. 18. Serum of a healthy adult male (Healthy adult control 9; $20 \mathrm{y}$, male) was obtained from the Okayama University. Other conditions were as described in the Materials and Methods section.

Table 3: Kinetic parameters of the glycoprotein enzyme of biotinidase: effects of glycosidases and fucoidan in vitro.

patients has been already reported by us [24]. Biotin status in these juvenile IDDM cases has not been studied, however biotin-deficient state in IDDM patients has been suggested by Coggeshall et al. [25]. It has also been reported that the suitable metabolic condition is required for the membrane proteins to be incorporated into cell membranes in bacteria [26]. Further, biotin is known to induce the incorporation of membrane-protein (asialoglycoprotein receptor) into the membrane compartment of HepG2 cells [27]. Therefore, biotin-deficiency induces the unique membrane protein UHS-KAP to extrude from the membrane compartment of the skin into the blood, and suitable amount of free biotin in the body corrects the expression of UHS-KAP into the membranes of the skin.

Child patient 1 shows seizure (status epilepticus; epileptic seizure) due to hypoglycemic encephalopathy or to biotin deficiency [1]. We have detected in her serum that brain membrane proteins of ion transporting proteins (vacuolar proton pump subunit $\mathrm{H}(416-)$, potassium voltage-gated channel subfamily $\mathrm{H}$ member 5 (320-), calcium-binding mitochondrial carrier protein SCaMC-1 (427-), sodium bicarbonate transporter-like protein 11 (118-), and brain calcium channel II (1883-)) before biotin therapy (Supplementary data 3). All these hydrophobic membrane transport-proteins are disappeared after the biotin therapy (Supplementary data 3). Further, nervous disorder patients of Adult 
Citation: Abe K, Hayakawa K, Ihara K, Deguchi K, Nagamine T (2015) Changes in the Hydrophobic Proteins in Response to Biotin Administration in Serum of Infant Patients with Alopecia as Assessed by the Protein Micro-Sequencing Method. J Microb Biochem Technol 7: 039-046. doi:10.4172/1948-5948.1000179

patient 5 (serious gait disorder and contraction) excreted nervous membrane proteins of potassium channel subfamily $\mathrm{K}$ member 1 (290-), chloride channel protein 4 (585-), and sodium channel protein type 8 subunit alpha (710-), and Adult patient's sister 6 with slight gait disorder and contraction also excreted sodium/calcium exchanger 3 (735-) and inward rectifier $\mathrm{K}^{+}$channel Kir2.4 (78-) into their bloods (Supplementary data 3).

These results suggest that biotin-deficiency may also induce the ion-transporting membrane proteins of the brain into the blood, and biotin may correct the expression of ion-transporting membrane proteins of the brain into the membranes of the nerve cells.

With respect to inflammation phenomenon among our biotindeficient patients, increase of invaded microbes in the serum and the appearance of ceruloplasmin fragment (214-) seems to be important. Humans has no Asp-D endopeptidase (zinc-containing enzyme), and bacterial enzyme can only cleave and produce fragment of ceruloplasmin (from 214 Asp-). Thus, patient of biotin deficiency seems to be in a state of bacterial infection and/or inflammation (dermatitis), and this state cannot be healed by long-period of biotin administration; i.e., biotin deficiency can surely be cured by biotin, but associated inflammation cannot be healed. Therefore, long period of oral biotin-administration is not recommended. Thus, c.a. 3-4 mo of oral biotin-treatment may be optimum to change the state of biotin deficiency, and disappearance of UHS-KAP and OR in the serum is a good indicator of stopping biotin therapy in the child.

Concentrations of serum biotinidase in the biotin-deficient children unexpectedly do not change by the oral biotin administration. This suggests that biotin does not influence on the gene expression of biotinidase during 4 mo of biotin-administration.

With respect to the pathophysiology of symptoms associated to biotin deficiency, dependence on the age seems to be important. Alopecia and eczema are occurred in the infant patients ( $0-3$ years old) as shown in this paper. One infant patient (2 years old female) with Coffin-Siris syndrome has shown sparse scalp hair, chronic intractable eczema, and nail hypoplasia [28]. Atopic dermatitis, eczema, bronchial asthma, allergic rhinitis, and conjunctivitis are observed in the child patients (9-14 years old), although serum membrane proteins has not been studied [10]. Two/four of the atopic dermatitis children have high inflammation-related antibody of immunoglobulin E (IgE) [10]. One child patient (10 years old male) has shown the late onset bilateral optic neuropathy and gait disorder (pyramidal signs in the lower limbs), and long period ( 6 months) is required to heal these nervous symptoms by biotin therapy [29]. One adult patient of 32 years old has shown the nervous symptomsof gait disorder and contraction as described above. These observations suggest that most actively developing and rapidly growing organs at the age are the targets of the deficiency of biotin.

Thermal instability of biotin-deficient patients' biotinidase is recovered in vitro by fucoidan (Table 3). Furthermore, fucoidan has anti-microbial activities to bacteria [30], DNA virus [31], and RNA virus [32]. Then, simultaneous administration of fucoidan and freeform biotin may be effective, since fucoidan prevents inflammation due to invaded microbes and recovers biotinidase kinetics via glycochain.

Since long biotin-administration by oral administration of freebiotin cannot cure the state of inflammation as in the case of Child patient 3, we alternatively have devised Ebios-Yakult therapy by cooperation with one of co-author K. Deguchi for adult biotin-deficient patient. We have previously found that Ebios (dried yeast) contains high amount of bound-form biotin [17] and Lactobacillus casei
(Shirota) in Yakult contains high $V$ of bacterial biotinidase [9]. Then, we have hypothesized that simultaneous oral-administration of Ebios and Yakult could liberate free biotin within the gut, and biotin level in serum could be elevated. Surely, this Adult patient 5 with gait disorder is improved the biotin status; i.e., from 1.14 (total) and 0.04 (free)

$\mu \mathrm{g} / \mathrm{mL}$ (before therapy; Table 2) to 2.04 (total) and 0.08 (free) $\mu \mathrm{g} /$ $\mathrm{mL}$ after $4 \mathrm{mo}$ of therapy, and also to 2.57 (total) and 0.29 (free) $\mu \mathrm{g} / \mathrm{mL}$ after $1.5 \mathrm{y}$ of therapy. Free biotin in the serum is increased for 7.3 -fold during $1.5 \mathrm{y}$ of this therapy. The symptoms of this patient seem to be slightly improved by this new therapy [18]

In the case of Adult patient 5 with gait disorder, ATX, OR, and PLXA proteins are detected, but KAP is not. KAP may be a specific marker for children's alopecia, since adult gait-disorder patient does not show symptom of alopecia. OR is detected in serum of the patient's family (her sister and mother), although her father's serum is not able to be tested (died of gall-bladder cancer). This may indicate that biotin deficient state is a familial and an economical phenomenon. Fragments of OR found in the serum of biotin deficiency are allglycochain-free hydrophobic fragments except fragment of OR $8 U 9$ of the Adult patient $5\left(\mathrm{~N}\right.$-glycosylated at $186^{\text {th }} \mathrm{N}$ ) (Supplementary data 3 ). Thus, excretion of glycochain-containing OR fragment into serum may be linked to the gait disorder and/or contraction.

ATX in the serum of Adult patient 5 seems to be important for the serious gait disorder. Although OR and PLXA are hydrophobic membrane glycoproteins, ATX is a hydrophilic cytoplasmic glycoprotein (but related to metabolism of membrane-glycoprotein). Fragments of ATX-2 and ATX-7-like protein 1 have glyco-chains at $1137^{\text {th }}$ and $818^{\text {th }}$ $\mathrm{N}$, respectively, and the excretion of glycoprotein into blood may be related membrane-degeneration diseases in brain. Immediate effect of biotin on the metabolism of membrane protein KAP is remarkable, but effect of biotin onto the metabolism of cytoplasmic proteins may be slower. The observations indicate that the metabolism of membrane glycoproteins in adult is different from in child. Furthermore, adult serum contains extremely large soluble glycoprotein of connectin/titin [8]. Then, complete healing of adult gait-disorder (neuro-degenerative disease) may be difficult by the interference of connectin/titin in the adult serum, however the biotin therapy using a combination of foodstuffs of Ebios-Yakult-fucoidan is now in progress by us.

Since hydrophobic membrane and high-sulphur/cysteine proteins are difficult to purify in the separation sciences of the state-of-the-art technology. Determination of such high-sulphur containing molecules directly is difficult issue even at this time; i.e., recovery rate of free-form lipoic acid from fresh human serum is $69.8 \%$, and correction by this recovery value has been performed [33]. Therefore, this is the first to demonstrate such high-sulphur containing molecule of UHS-KAP in fresh human serum by using our unique quantitative PDMD method. This method uses prior protection of cysteine-residues of serum proteins by pyridylethylation. PDMD method is performed by directly binding the serum proteins to glass-fiber discs. Cysteine in the serum proteins is determined by produced pyridylethylated cysteine (PEC) without using separation technology.

Since the molecular weights of these hydrophobic membraneproteins (UHS-KAP, OR, PLXA) and ATX are less than 46,000, application of PDMD method after size-exclusion chromatographic (SEC) separation using non-ionic detergent [9] together with the PECderivatization of serum proteins [3] may become the powerful tool for the prompt biotechnological diagnosis. 
Citation: Abe K, Hayakawa K, Ihara K, Deguchi K, Nagamine T (2015) Changes in the Hydrophobic Proteins in Response to Biotin Administration in Serum of Infant Patients with Alopecia as Assessed by the Protein Micro-Sequencing Method. J Microb Biochem Technol 7: 039-046. doi:10.4172/1948-5948.1000179

\section{Conclusion}

(1) The serum proteins of biotin-deficient children with alopecia were comparatively studied.

(2) Membrane protein of UHS-KAP was appeared in the serum of alopecia children, and disappeared by the biotin treatment. Biotinadministration healed three alopecia children.

(3) The adult serum of biotin-deficient gait disorder patient contained the membrane-metabolism related protein (ATX).

(4) This PDMD method clarified that biotin is the possible regulator for membrane biosynthesis.

\section{References}

1. Ihara K, Abe K, Hayakawa K, Makimura M, Kojima-Ishii K, et al. (2011) Biotin deficiency in a glycogen storage disease type $1 \mathrm{~b}$ girl fed only with glycogen storage disease-related formula. Pediatr Dermatol 28: 339-341.

2. Edman $P$ (1956) Mechanism of the phenyl isothiocyanate degradation of peptides. Nature 177: 667-668.

3. Hayakawa K, Nagamine T (2014) Fucoidan-dependent increased membrane components in HepG2 cells: effect of fucoidan is not due to gene expression. Cancer Genomics \& Proteomics 11: 93-114.

4. Gong H, Zhou H, McKenzie GW, Yu Z, Clerens S, et al. (2012) An updated nomenclature for keratin-associated proteins (KAPs). Int J Biol Sci 8: 258-264.

5. Gaillard I, Rouquier S, Giorgi D (2004) Olfactory receptors. Cell Mol Life Sci 61: 456-469.

6. Negishi M, Oinuma I, Katoh H (2005) Plexins: axon guidance and signal transduction. Cell Mol Life Sci 62: 1363-1371.

7. Orr HT (2012) Cell biology of spinocerebellar ataxia. J Cell Biol 197: 167-177.

8. Maruyama K (1997) Connectin/titin, giant elastic protein of muscle. FASEB $J$ 11: $341-345$

9. Hayakawa K, Guo L, Terentyeva EA, Li XK, Kimura H, et al. (2006) Determination of specific activities and kinetic constants of biotinidase and lipoamidase in LEW rat and Lactobacillus casei (Shirota). J Chromatogr B Analyt Technol Biomed Life Sci 844: 240-250.

10. likura $Y$, Odajima $Y$, Nagakura T, linuma K, Hayakawa K, et al. (1988) Ora biotin treatment is effective for atopic dermatitis in children with low biotinidase activity. Acta Paediatr Scand 77: 762-763.

11. Hayakawa K, Guo L, Terentyeva EA, Li XK, Kimura H, et al. (2003) Sizeexclusion chromatography of biological samples which contain extremely alkaline proteins. J Biochem Biophys Methods 56: 153-163.

12. Salnikow J, Lehmann A, Wittmann-Liebold B (1981) Improved automated solidphase microsequencing of peptides using DABITC. Anal Biochem 117: 433-442.

13. Hayakawa K, Guo L, Li XK, Kimura H, Yoshinaga T, et al. (2001) Highperformance liquid chromatographic protein determination. Curr Top Anal Chem 2: 195-200.

14. Hayakawa K, Yoshikawa K, Watanabe T (1994) Biotinidase: determinations of enzyme-activity, chemical structures such as glycochain structure and amino-acid sequence, and potential physiological roles of the enzyme and the possibility of biotinidase onto clinical applications. Vitamins (Kyoto) 68: 318-320

15. Cole H, Reynolds TR, Lockyer JM, Buck GA, Denson T, et al. (1994) Human serum biotinidase. cDNA cloning, sequence, and characterization. J Biol Chem 269: 6566-6570.

16. Kawakami H, Hayakawa K, Nagata K, Tanokura M (2013) Proteomic analysis of impurities coexisted with lactoferrin. Milk Science (Japan) 62: 29-37

17. Hayakawa K1, Katsumata N, Hirano M, Yoshikawa K, Ogata T, et al (2008) Determination of biotin (vitamin $\mathrm{H}$ ) by the high-performance affinity chromatography with a trypsin-treated avidin-bound column. J Chromatogr B Analyt Technol Biomed Life Sci 869: 93-100.

18. Hayakawa K1, Katsumata N1, Abe K1, Hirano M1, Yoshikawa K1, et al. (2009) Wide Range of Biotin (Vitamin $\mathrm{H}$ ) Content in Foodstuffs and Powdered Milks as Assessed by High-performance Affinity Chromatography. Clin Pediatr Endocrinol 18: 41-49.
19. De Felice C1, Hayakawa K, Nihei K, Higuchi S, Tanaka T, et al. (1994) Changes in cerebrospinal fluid biotinidase activity in Staphylococcus aureus meningitis Brain Dev 16: 156-158.

20. Michael HP, Aaron GD (2012) ALS-associated ataxin 2 polyQ expansions enhance stress-induced caspase 3 activation and increase TDP-43 pathological modifications. J Neuroscience 32: 9133-9142.

21. Helmlinger D, Hardy S, Sasorith S, Klein F, Robert F, et al. (2004) Ataxin-7 is a subunit of GCN5 histone acetyltransferase-containing complexes. Hum Mol Genet 13: 1257-1265.

22. Buffoli B1, Rinaldi F, Labanca M, Sorbellini E, Trink A, et al. (2014) The human hair: from anatomy to physiology. Int J Dermatol 53: 331-341.

23. Nilsson L, Kågedal B (1993) Co-purification of human serum lipoamidase and biotinidase: evidence that the two enzyme activities are due to the same enzyme protein. Biochem J 291 : 545-551.

24. Terentyeva EA, Hayakawa K, Tanae A, Katsumata N, Tanaka T, et al. (1997) Urinary biotinidase and alanine excretion in patients with insulin-dependent diabetes mellitus. Eur J Clin Chem Clin Biochem 35: 21-24.

25. Coggeshall JC, Heggers JP, Robson MC, Baker H (1985) Biotin status and plasma glucose in diabetics: Biotin. Ann NY Acad Sci 447: 389-392.

26. Kusaka I, Hayakawa K, Kanai K, Fukui S (1976) Isolation and characterization of hydrophobic proteins (H proteins) in the membrane fraction of Bacillus subtilis. Involvement in membrane biosynthesis and the formation of biochemically active membrane vesicles by combining $\mathrm{H}$ proteins with lipid. Eur $\mathrm{J}$ Biochem 71: $451-458$

27. Collins JC, Paietta E, Green R, Morell AG, Stockert RJ (1988) Biotin-dependent expression of the asialoglycoprotein receptor in HepG2. J Biol Chem 263: $11280-11283$

28. Burlina AB1, Sherwood WG, Zacchello F (1990) Partial biotinidase deficiency associated with Coffin-Siris syndrome. Eur J Pediatr 149: 628-629.

29. Ramaekers VT1, Suormala TM, Brab M, Duran R, Heimann G, et al. (1992) A biotinidase $\mathrm{Km}$ variant causing late onset bilateral optic neuropathy. Arch Dis Child 67: 115-119.

30. Zapopozhets TS, Besednova NN, Loenko luN (1995) [Antibacterial and immunomodulating activity of fucoidan]. Antibiot Khimioter 40: 9-13.

31. Hayashi K, Nakano T, Hashimoto M, Kanekiyo K, Hayashi T (2008) Defensive effects of a fucoidan from brown alga Undaria pinnatifida against herpes simplex virus infection. Int Immunopharmacol 8: 109-116.

32. Mori N, Nakasone K, Tomimori K, Ishikawa C (2012) Beneficial effects of fucoidan in patients with chronic hepatitis $\mathrm{C}$ virus infection. World J Gastroenterol 18: 2225-2230.

33. Hayakawa K, Katsumata N, Yoshikawa K, Hirano M, Ogata T, et.al. (2007) Determination of lipoic (thioctic) acid by high-performance affinity chromatography with a trypsin-treated avidin-bound column. Trends in Chromatogr 3: 31-42. 